\title{
Public Interest in Acne on the Internet: Comparison of Search Information From Google Trends and Naver
}

Tae Heum Park ${ }^{1}$, MD; Woo Il Kim ${ }^{1}$, MD; Suyeon Park ${ }^{2}$, PhD; Jaeouk Ahn ${ }^{3}$, PhD, MD; Moon Kyun Cho ${ }^{1}$ PhD, MD; Sooyoung $\mathrm{Kim}^{1}$, MD

${ }_{1}^{1}$ Department of Dermatology, Soonchunhyang University Hospital, Seoul, Republic of Korea
${ }^{2}$ Department of Biostatistics, Soonchunhyang University Hospital, Seoul, Republic of Korea
${ }^{3}$ Department of Medical IT Engineering, Soonchunhyang University, Asan, Republic of Korea

Corresponding Author:

Sooyoung Kim, MD

Department of Dermatology

Soonchunhyang University Hospital

59, Daesagwan-ro

Yongsan-gu

Seoul,

Republic of Korea

Phone: 8227099368

Fax: 8227099374

Email: $\underline{\text { skim1@schmc.ac.kr }}$

\section{Abstract}

Background: Acne vulgaris is a common skin disease primarily affecting young adults. Given that the internet has become a major source of health information, especially among the young, the internet is a powerful tool of communication and has a significant influence on patients.

Objective: This study aimed to clarify the features of patients' interest in and evaluate the quality of information about acne vulgaris on the internet.

Methods: We compared the search volumes on acne vulgaris with those of other dermatological diseases using Google Trends from January 2004 to August 2019. We also determined the search volumes for relevant keywords of acne vulgaris on Google and Naver and evaluated the quality of answers to the queries in KnowledgeiN.

Results: The regression analysis of Google Trends data demonstrated that the patients' interest in acne vulgaris was higher than that for other dermatological diseases, such as atopic dermatitis $(\beta=-20.33,95 \% \mathrm{CI}-22.27$ to $-18.39, P<.001)$ and urticaria $(\beta=-27.09,95 \%$ CI -29.03 to $-25.15, P<.001)$ and has increased yearly $(\beta=2.38,95 \%$ CI 2.05 to $2.71, P<.001)$. The search volume for acne vulgaris was significantly higher in the summer than in the spring $(\beta=-5.04,95 \% \mathrm{CI}-9.21$ to $-0.88, P=.018)$ and on weekends than on weekdays $(\beta=-6.68,95 \% \mathrm{CI}-13.18$ to $-0.18, P=.044)$. The most frequently searched relevant keywords with "acne vulgaris" and "cause" were "stress," "food," and "cosmetics." Among food, the 2 highest acne vulgaris-related keywords were milk and wheat in Naver and coffee and ramen in Google. The queries in Naver KnowledgeiN were mostly answered by a Korean traditional medicine doctor (53.4\%) or the public (33.6\%), but only $12.0 \%$ by dermatologists.

Conclusions: Physicians should be aware of patients' interest in and beliefs about acne vulgaris to provide the best patient education and care, both online and in the clinic.

(J Med Internet Res 2020;22(10):e19427) doi: 10.2196/19427

\section{KEYWORDS}

acne vulgaris; internet; infodemiology; infoveillance; cosmetics; diet; dermatology; Google 


\section{Introduction}

\section{Background}

The internet has spread widely since the 1980s and has become a powerful tool and route of communication. People increasingly use it to find information about health problems. According to the Measuring the Information Society Report from 2018 by the International Telecommunication Union, the internet usage rate in South Korea was $95.10 \%$ in 2018 [1]. According to 2018 internet usage statistics by the Ministry of Science and Information and Communications Technology of South Korea, the internet usage rate was $91.5 \%(46,124,694$ persons), and the average daily internet usage time in South Korea was 2 hours 15 minutes [2]. As internet usage increases, the influence of the internet is also growing. According to the 2018 internet usage statistics by the Ministry of Science and Information and Communications Technology of South Korea, we use it for viewing movies, videos, and images (87.0\%); shopping (62.0\%); banking (63.7\%); and communication through messengers $(95.9 \%)$ [2]. In the face of the rapid expansion of smartphones, smartphones have made the internet more ubiquitous; we can get any information wherever we are, which contributes to the percentage of people using the mobile internet (90.4\%) in 2018 in South Korea. In particular, young people actively use the internet to exchange their thoughts and get information, including medical and health care information. Among people aged in their $10 \mathrm{~s}, 20 \mathrm{~s}$, and $30 \mathrm{~s}$, the ratios of people using the internet were $99.9 \%, 99.9 \%$, and $99.9 \%$, respectively, and those of people using the mobile internet were $98.7 \%, 99.9 \%$, and $99.9 \%$, respectively [2].

Acne vulgaris is a very common dermatological disease and the 8th most common disease worldwide; it is estimated to affect 633 million people globally $[3,4]$. It primarily affects young adults, mostly in their teens, 20s, and 30s [5]. Four mechanisms are considered important in the pathogenesis of acne vulgaris: (1) sebaceous hypersecretion, (2) hair follicle hyperkeratosis, (3) colonization of Cutibacterium acnes, and (4) inflammatory reactions [6]. External factors such as the environment are also known as important risk factors. Mechanical stimulation like friction, psychological stress [7], and excessive sweating have also been suggested as causes of acne vulgaris. Food is also a possible cause, but the relationship is still unclear, even though there are studies that show a relationship between acne vulgaris and food. The most commonly involved site of acne vulgaris is the face, followed by the neck, back, and chest. Clinically, various kinds of skin lesions are possible: comedon, papule, pustule, and nodule. Deep skin lesions can result in scars, and it is estimated that $95 \%$ of acne vulgaris patients have acne scars [8], which can induce serious psychosocial problems [4].

\section{Goal of This Study}

Acne vulgaris is prevalent. It is observed in $80 \%-90 \%$ of adolescents and young adults, and it has high social interest because of its cosmetic sequelae and psychosocial problems. The purpose of this study was to clarify the features of patients' interest in and evaluate the quality of information about acne vulgaris on the internet. Therefore, we aimed to investigate public interest in acne vulgaris by assessing the search volume of acne vulgaris-related keywords through the major search sites (Naver, Google) that are widely used in South Korea. In addition, we analyzed who answered questions about acne vulgaris on the internet and evaluated the answers posted on internet sites to investigate the accuracy of the information on the internet for public health.

\section{Methods}

\section{Study Design}

We used the search portal sites Naver and Google, which are among the most commonly used search sites in South Korea.

First, we compared the interest in acne vulgaris and other dermatological diseases by using Google Trends, a website that analyzes the popularity of top search queries in Google Search across various regions and languages. Google Trends provides a search volume index (0 to 100), which is the search volume relative to the total number of searches performed on Google. We compared the public interest in acne vulgaris to that of other dermatological disorders, such as atopic dermatitis or urticaria, as well as the yearly and seasonal trends in interest, using regression analysis of 15 years' worth of Google Trends data. From the regression analysis of Google Trends 90-day data, we looked at whether there is a difference between interest on weekends and on weekdays. To determine whether there is a correlation between Google Trends geographic data and personal income, private consumption, or composition of the population, we performed correlation analyses. Keywords used for the search were "acne vulgaris," "urticaria" (urticae or urtica were not included), and "atopic dermatitis" (atopic eczema was also included) in Korean.

Next, we compared search volumes using keywords for "acne vulgaris, treatment," "acne vulgaris, laser," "acne vulgaris, cause," "acne vulgaris, diet," and "acne vulgaris, cosmetics" in Korean in Google and Naver KnowledgeiN. We also sorted 500 answers by responders (dermatologist, general practitioner or specialist medical doctor, Korean medicine doctor, or general public) in Naver KnowledgeiN.

\section{Statistical Analysis}

We used linear regression analysis to observe yearly trends and seasonal trends; correlation analysis to determine correlations between Google Trends geographic data and personal income, private consumption, or composition of population; and text mining to express the search volume of acne vulgaris-related keywords. The statistics program R 3.6.2 was used to analyze data, and $P<.05$ was considered statistically significant.

\section{Results}

\section{Acne Vulgaris is One of the Most Popular Dermatological Diseases on the Internet}

The regression analysis of Google Trends data for 15 years demonstrated that patients' interest in acne vulgaris was higher than the interest in atopic dermatitis $(\beta=-20.33,95 \% \mathrm{CI}-22.27$ to $-18.39, P<.001)$ and urticaria $(\beta=-27.09,95 \% \mathrm{CI}-29.03$ to $-25.15, P<.001)$. Public interest in acne vulgaris has increased yearly $(\beta=2.38,95 \%$ CI 2.05 to $2.71, P<.001)$ and was higher 
in summer than in spring $(\beta=-5.04,95 \% \mathrm{CI}-9.21$ to -0.88 , $P=.018$ ). But there was no significant difference between other seasons. For the temporal trends between weekends and weekdays, the interest in acne vulgaris on weekends was higher than on weekdays $(\beta=-6.68,95 \% \mathrm{CI}-13.18$ to $-0.18, P=.044$; Figure 1).

Figure 1. Temporal trends in searches for acne: (A) Google Trends time data (15 years). The search volume index (0 to 100) represents the search volumes relative to the total number of Google searches. (B) Google Trends time data (90 days). The horizontal bars indicate weekends.

$$
\begin{aligned}
& \text { Search } \\
& \text { volume } \\
& \text { index }
\end{aligned}
$$

(A) 100

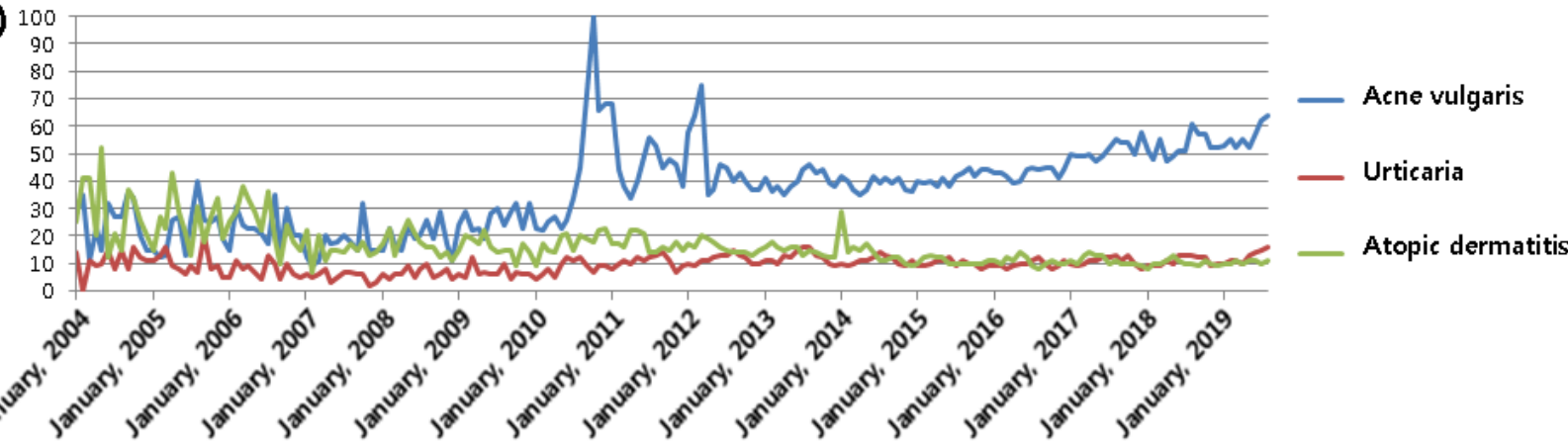

\section{Search}

$$
\text { volume }
$$

(B)

$$
\text { index }
$$

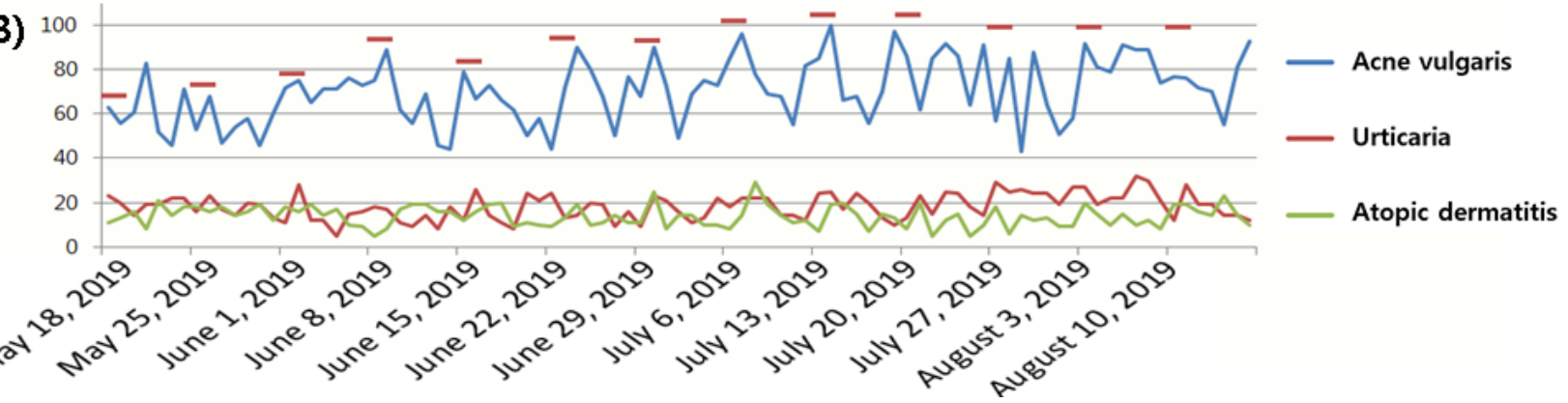

\section{Seoul Has the Greatest Interest in Acne Vulgaris on the Internet Among Cities and Provinces}

We also determined interest in acne vulgaris among cities and provinces through Google Trends geographic data. Seoul had the highest interest in acne vulgaris among cities and provinces, followed by Incheon and Daegu. Jeollabuk-do and
Chungcheongbuk-do had the lowest interest. There was no significant correlation between search volumes and personal income (correlation coefficient $=0.30, P=.27$ ) or between search volumes and private consumption (correlation coefficient $=0.37$, $P=.16$; Table 1; Figure 2). There was also no significant correlation between search volume and age (Table 2). 
Table 1. Acne vulgaris search volume and personal income in cities and provinces.

\begin{tabular}{llll}
\hline Cities and provinces & Search volume & Personal income (annual, KRW) & Private consumption (annual, KRW) \\
\hline Seoul & 100 & $21,429,000$ & $20,211,000$ \\
Incheon & 91 & $17,550,000$ & $14,486,000$ \\
Daegu & 88 & $17,568,000$ & $15,682,000$ \\
Gwangju & 81 & $17,343,000$ & $16,122,000$ \\
Jeju & 79 & $17,464,000$ & $15,107,000$ \\
Gyeongsangnam-do & 78 & $16,864,000$ & $14,735,000$ \\
Daejeon & 77 & $18,454,000$ & $16,286,000$ \\
Busan & 76 & $18,332,000$ & $16,208,000$ \\
Chungcheongnam-do & 75 & $17,613,000$ & $14,047,000$ \\
Jeollanam-do & 75 & $15,938,000$ & $14,112,000$ \\
Gyeonggi-do & 74 & $18,580,000$ & $15,786,000$ \\
Gyeongsangbuk-do & 74 & $16,504,000$ & $14,395,000$ \\
Gangwon-do & 74 & $16,583,000$ & $14,957,000$ \\
Ulsan & 73 & $19,912,000$ & $16,494,000$ \\
Jeollabuk-do & 71 & $16,848,000$ & $14,194,000$ \\
Chungcheongbuk-do & 71 & $17,030,000$ & $14,381,000$ \\
\hline
\end{tabular}

Figure 2. Regional trends in internet searches for acne.
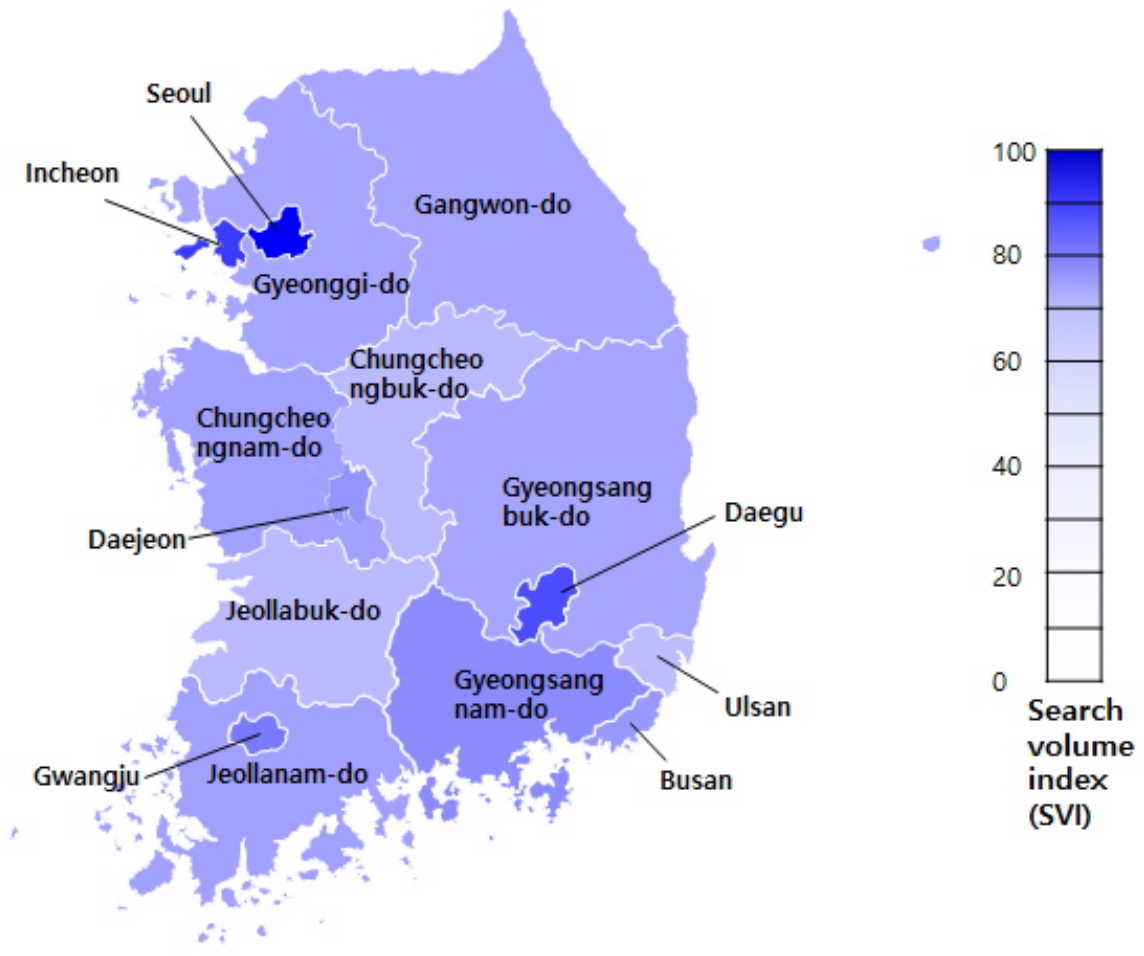
Table 2. Acne vulgaris search volume and population composition in cities and provinces.

\begin{tabular}{|c|c|c|c|c|c|c|c|c|c|}
\hline \multirow[t]{2}{*}{ Cities and provinces } & \multicolumn{3}{|c|}{ Search volume } & \multicolumn{6}{|c|}{ Ratio of the population in the age range, $\%$} \\
\hline & 2018 & 2017 & 2016 & $\begin{array}{l}10 \mathrm{~s} \text { to } 20 \mathrm{~s} \\
(2018)\end{array}$ & $\begin{array}{l}10 \mathrm{~s} \\
(2018)\end{array}$ & $\begin{array}{l}10 \mathrm{~s} \text { to } 20 \mathrm{~s} \\
(2017)\end{array}$ & $\begin{array}{l}10 \mathrm{~s} \\
(2017)\end{array}$ & $\begin{array}{l}10 \mathrm{~s} \text { to } 20 \mathrm{~s} \\
(2016)\end{array}$ & $\begin{array}{l}10 \mathrm{~s} \\
(2016)\end{array}$ \\
\hline Seoul & 100 & 100 & 89 & 23.60 & 8.76 & 23.76 & 9.08 & 23.94 & 9.41 \\
\hline Incheon & 83 & 81 & 95 & 23.76 & 9.89 & 24.13 & 10.23 & 24.40 & 10.58 \\
\hline Gwangju & 73 & 82 & 69 & 25.88 & 11.78 & 26.19 & 12.28 & 26.48 & 12.77 \\
\hline Jeju & 90 & 78 & 100 & 23.30 & 11.05 & 23.53 & 11.39 & 23.74 & 11.81 \\
\hline Gyeongsangnam-do & 77 & 80 & 80 & 21.93 & 10.25 & 22.31 & 10.56 & 22.68 & 10.90 \\
\hline Daejeon & 82 & 69 & 99 & 25.13 & 10.77 & 25.43 & 11.18 & 25.67 & 11.62 \\
\hline Chungcheongnam-do & 70 & 70 & 88 & 21.73 & 10.04 & 22.05 & 10.32 & 22.35 & 10.61 \\
\hline Jeollanam-do & 76 & 76 & 81 & 20.73 & 9.75 & 21.04 & 10.11 & 21.34 & 10.50 \\
\hline Gyeonggi-do & 77 & 72 & 76 & 23.97 & 10.59 & 24.33 & 10.96 & 24.59 & 11.32 \\
\hline Gyeongsangbuk-do & 81 & 69 & 71 & 20.37 & 9.16 & 20.80 & 9.45 & 21.22 & 9.80 \\
\hline Gangwon-do & 80 & 66 & 73 & 21.58 & 9.72 & 22.12 & 10.12 & 22.46 & 10.54 \\
\hline Ulsan & 63 & 73 & 68 & 23.79 & 10.52 & 24.36 & 10.89 & 24.86 & 11.32 \\
\hline Jeollabuk-do & 74 & 64 & 72 & 22.23 & 10.39 & 22.64 & 10.78 & 22.90 & 11.13 \\
\hline Chungcheongbuk-do & 85 & 73 & 58 & 22.55 & 10.27 & 22.92 & 10.40 & 23.24 & 10.79 \\
\hline
\end{tabular}

Most Frequently Searched Relevant Keywords Were Cosmetics, Food, Laser, and Hormone

We searched Naver KnowledgeiN and Google for topics combined with "acne vulgaris" in 5 areas: treatment, cause, cosmetics, laser, and food (Table 3).

When comparing the number of search results from Naver KnowledgeiN with that from Google, Google had a greater number of search results: "acne vulgaris and cause,"
1,078,537/12,797,237, 8.4\%, Naver and 11,718,700/12,797,237, 91.6\%, Google; "acne vulgaris and food," 257,137/5,740,137, $4.5 \%$, Naver and 5,483,000/5,740,137, 95.5\%, Google; "acne vulgaris and cosmetics," 1,250,879/14,097,879, 8.9\%, Naver and 12,847,000/14,097,879, 91.1\%, Google; "acne vulgaris and treatment," 277,918/2,035,700, 13.7\%, Naver and 1,757,782/2,035,700, 86.3\%, Google; and "acne vulgaris and laser," $159,158 / 1,908,158, \quad 8.3 \%, \quad$ Naver and $1,749,000 / 1,908,158,91.7 \%$, Google. 
Table 3. Frequently searched relevant keywords determined by text mining.

\begin{tabular}{|c|c|c|}
\hline Topic & Naver & Google \\
\hline \multicolumn{3}{|l|}{ Acne and cause } \\
\hline Stress & 371,735 & $1,520,000$ \\
\hline Food & 265,991 & $1,890,000$ \\
\hline Cosmetics & 29,249 & $6,630,000$ \\
\hline \multicolumn{3}{|l|}{ Acne and food } \\
\hline Milk & 57,135 & 478,000 \\
\hline Flour & 57,161 & 167,000 \\
\hline Coffee & 27,005 & $1,460,000$ \\
\hline Ramen & 4285 & $1,370,000$ \\
\hline \multicolumn{3}{|l|}{ Acne and cosmetics } \\
\hline Toner & 334,502 & $6,020,000$ \\
\hline Lotion & 332,153 & 814,000 \\
\hline Cleansing foams & 57,135 & 472,000 \\
\hline Essences & 68,667 & $1,250,000$ \\
\hline \multicolumn{3}{|l|}{ Acne and treatment } \\
\hline Lasers & 168,750 & $1,250,000$ \\
\hline Antibiotics & 54,363 & 184,000 \\
\hline \multicolumn{3}{|l|}{ Acne and laser } \\
\hline Fraxel laser & 40,542 & 154,000 \\
\hline Photodynamic therapy & 29,933 & 125,000 \\
\hline Toning laser & 18,613 & 428,000 \\
\hline Intense pulsed light & 16,379 & 280,000 \\
\hline LED & 1378 & 316,000 \\
\hline
\end{tabular}

\section{Information via the Internet Has Been Provided Mostly by Nonexperts}

We sorted 500 answers by responders in Naver KnowledgeiN. The queries in Naver KnowledgeiN were mostly answered by Korean traditional medical doctors $(267 / 500,53.4 \%)$, but only $12.0 \%(60 / 500)$ by dermatologists, $33.6 \%(168 / 500)$ by the public, and $1.0 \%(5 / 500)$ by a general practitioner or a specialist medical doctor. The most common question about acne vulgaris was treatment $(393 / 500,78.6 \%)$, followed by cause $(61 / 500$, $12.2 \%)$, cosmetics $(22 / 500,4.4 \%)$, and laser $(9 / 500,1.8 \%)$.

\section{Discussion}

\section{Principal Findings}

People have greater interest in acne vulgaris than in other dermatological disorders, and patients' interest in acne vulgaris has significantly increased yearly. There were also significant differences in interest between cities and provinces. But there were no significant correlations between public interest and personal income, private consumption, or composition of the population. We selected acne-related topics that people would be curious about: cause, food, cosmetics, treatment, and laser. Among the foods, there were many searches for milk, wheat, and coffee. Regarding lasers, Fraxel laser, photodynamic therapy
(Naver), toning laser, and LED (Google) were of high interest. Answers to the questions on the internet were mostly provided by Korean traditional medical doctors $(53.4 \%)$ or the public without expertise $(33.6 \%)$ and only $12.2 \%$ by dermatologists.

Public interest in beauty has been increasing in South Korea. According to the International Society of Aesthetic Plastic Surgery, the size of the Korean plastic surgery market was estimated at about 5 trillion won in 2017, which was about a quarter of the world market, and the annual number of plastic surgeries per 1000 people was estimated at 13.5, making it first in the world [9]. The market size of the cosmetics and plastic surgery industries in South Korea has been growing $[9,10]$, which could explain why the interest in acne vulgaris is high and increased much more abruptly than other dermatological disorders, such as atopic dermatitis. Another reason for this high interest may be that acne vulgaris mostly affects young people, who use the internet much more frequently.

People's lifestyles and thoughts are related to internet search volumes. Because acne vulgaris frequently affects young people who work or go to school on weekdays [5], the search volume for acne vulgaris was significantly higher on weekends than on weekdays. Conventionally, people might think that the higher their income, the more they care about their appearance, but there was no significant correlation between public interest and 
personal income or private consumption. From this, we can see that people's interest in beauty is universal regardless of economic condition. Related to this finding, some studies have revealed that concern about physical appearance has no association with socioeconomic status [11].

The internet can probably help to identify etiology and epidemiology of disease [12]. It is known that acne vulgaris tends to get worse in the summer $[13,14]$. High temperatures can change sebum excretion [15], which can worsen acne vulgaris. Consistently, we found that the search volume for acne vulgaris was significantly higher in summer than in spring. Several studies have suggested that dairy products, chocolate, and hyperglycemic foods, such as ramen and flour, can exacerbate acne vulgaris [16-22]. Consistent with these studies, we found that people frequently searched for ramen, flour, chocolate, or milk along with acne vulgaris. Stress and hormones, which were frequently searched by the public on the internet, are also well known to exacerbate acne vulgaris [7,23-25]. Similarly, there are many other studies attempting to estimate epidemiology or track outbreaks of various kinds of diseases, such as influenza, cellulitis, cancer, and tuberculosis, by using the internet $[12,26,27]$.

The power of mass media is extremely strong, even in the medical field $[28,29]$. In Figure 1A, there was a peak in search volume around the second week of October 2010, probably caused by news articles reported on October 13, 2010, from Korean major broadcasters such as MBC, SBS, or MBN that emphasized the relevance of food and acne vulgaris. In addition to conventional mass media, the internet, smartphones, and social media are also emerging as influential tools [30-32]. In 2010, there was an abrupt spread of smartphones in South Korea, which enabled people to get health information wherever they are and contributed to the peak of search volumes in 2010. Physicians can use the powerful internet in the medical field
[33]. First, through the internet, information about which the public is curious can be easily identified. Second, it can be a helpful tool for patient education because the internet is easily accessible and interactive and can provide media-based material, such as photos and videos. About this, especially in the field of skin cancer, several studies have shown that dermatologists can even effectively change people's skin-related health behavior through an internet intervention and can thus reduce the prevalence of skin diseases [34-36]. Through internet-based deep learning, diagnostic tools for skin cancer are even currently under development [37,38].

However, there is also the probability that false information could be provided, which can also be a major health risk. Much of the information was provided by nonexperts, such as the public or Korean traditional medical doctors, rather than by experts, that is, dermatologists, so the risk is high that false information might spread and endanger patients. Moreover, during data collection, we found manipulation for the purpose of promotion; in Naver KnowledgeiN, someone posted the same questions and adopted only one user as a best answer user. In this way, some people, if they have dishonest intentions, can spread misleading information very easily through the internet. Newspapers and TV news reports also have reported cases of adverse health effects because of incorrect medical information on the internet (Table 4). The Naver online café, Anaki, has greatly restricted the use of medicines for children and has even held chicken pox parties, causing a great deal of controversy. In addition, in the United States, conspiracy theories about vaccination spread on the internet, and the measles vaccination rate dropped significantly, which caused another measles pandemic [39]. As such, in the medical field, the internet has both aspects, in that helpful information can be provided to patients and yet wrong information can be provided and cause serious harm to patients.

Table 4. Risk cases for dissemination of unverified facts.

\begin{tabular}{ll}
\hline Source or harm & Example \\
\hline Anaki & $\begin{array}{l}\text { The Naver Café, with a membership as high as } 60,000 \text { people, caused problems with the dissemination of unfounded } \\
\text { medical information, such as neglecting children's illness, refusing vaccinations, throwing chicken pox parties, and selling } \\
\text { untested medicines. }\end{array}$
\end{tabular}

Anyemo

This antivaccine movement website refused vaccinations without any reasonable evidence, which could cause pandemics of infectious diseases.

Measles epidemic in the The measles epidemic in the United States has greatly increased because of the decrease in vaccination resulting from United States unfounded stories about vaccination spread through social media platforms such as Facebook.

\section{Limitations}

There are several limitations to this study. First, Google Trends provides only a relative search volume index, not the absolute search volume, and does not provide a way to calculate the search volume index. Second, we could not find statistically significant factors affecting geographic differences. Personal income, personal consumption, and composition of the population had only weak positive correlations with acne vulgaris. Third, there are many advertisements about acne vulgaris, which might not represent the real interest of the public. Fourth, we could not analyze the exact accuracy of information, but only estimate its quality through the ratio of who answered the questions in Naver KnowledgeiN. Last, it is not an interventional study. Further interventional studies are needed to measure the real effect of the internet in the real world.

\section{Conclusions}

As part of patient education, we dermatologists need to correct wrong information. In addition, we can use the internet for patient education by launching official websites that provide accurate information about skin diseases or by operating dermatologists' Q\&A sites. As such, we need to try both in and outside the office to understand people's interests and beliefs in the internet space and try to intervene through the internet 
and smartphones to provide the best treatment and education for patients with skin diseases.

\section{Acknowledgments}

This work was supported by the Soonchunhyang University Research Fund (number 20191261).

\section{Conflicts of Interest}

None declared.

\section{References}

1. Measuring the Information Society Report, Volume 1. International Telecommunication Union. 2018. URL: https://www. itu.int/en/ITU-D/Statistics/Documents/publications/misr2018/MISR-2018-Vol-1-E.pdf [accessed 2020-09-22]

2. No M, Heo Y, Choi Y, Lee H. 2018 Survey on the Internet Usage. Korean Ministry of Science and ICT. URL: https://tinyurl. com/yyefhjzk [accessed 2020-09-22]

3. GBD 2015 Disease and Injury Incidence and Prevalence Collaborators. Global, regional, and national incidence, prevalence, and years lived with disability for 310 diseases and injuries, 1990-2015: a systematic analysis for the Global Burden of Disease Study 2015. The Lancet 2016 Oct 8;388(10053):1545-1602 [FREE Full text] [doi: 10.1016/S0140-6736(16)31678-6] [Medline: 27733282]

4. Dawson AL, Dellavalle RP. Acne vulgaris. BMJ 2013 May 08;346:f2634. [doi: 10.1136/bmj.f2634] [Medline: 23657180]

5. Bhate K, Williams HC. Epidemiology of acne vulgaris. Br J Dermatol 2013 Mar;168(3):474-485. [doi: 10.1111/bjd.12149] [Medline: 23210645]

6. Simonart T. Immunotherapy for acne vulgaris: current status and future directions. Am J Clin Dermatol 2013 Dec;14(6):429-435. [doi: 10.1007/s40257-013-0042-8] [Medline: 24019180]

7. Orion E, Wolf R. Psychologic factors in the development of facial dermatoses. Clin Dermatol 2014;32(6):763-766. [doi: 10.1016/j.clindermatol.2014.02.015] [Medline: 25441469]

8. Fife D. Evaluation of Acne Scars: How to Assess Them and What to Tell the Patient. Dermatol Clin 2016 Apr;34(2):207-213. [doi: 10.1016/j.det.2015.11.009] [Medline: 27015781]

9. Plastic Makes Perfect. The Economist. 2013 Jan 30. URL: https://www.economist.com/graphic-detail/2013/01/30/ plastic-makes-perfect [accessed 2020-09-22]

10. The International Trade Administration (ITA). South Korea Country Commercial Guide. US Department of Commerce. 2020 Oct 05. URL: https://www.trade.gov/country-commercial-guides/south-korea-market-overview [accessed 2020-10-15]

11. Harris DL, Carr AT. Prevalence of concern about physical appearance in the general population. British Journal of Plastic Surgery 2001 May;54(3):223-226. [doi: 10.1054/bjps.2001.3550] [Medline: 11254414]

12. Cervellin G, Comelli I, Lippi G. Is Google Trends a reliable tool for digital epidemiology? Insights from different clinical settings. J Epidemiol Glob Health 2017 Sep;7(3):185-189. [doi: 10.1016/j.jegh.2017.06.001] [Medline: 28756828]

13. Celis-Morales C, Livingstone KM, Petermann-Rocha F, Navas-Carretero S, San-Cristobal R, O'Donovan CB, Food4Me Study. Frequent Nutritional Feedback, Personalized Advice, and Behavioral Changes: Findings from the European Food4Me Internet-Based RCT. Am J Prev Med 2019 Aug;57(2):209-219. [doi: 10.1016/j.amepre.2019.03.024] [Medline: 31248745]

14. Narang I, Sardana K, Bajpai R, Garg VK. Seasonal aggravation of acne in summers and the effect of temperature and humidity in a study in a tropical setting. J Cosmet Dermatol 2019 Aug;18(4):1098-1104. [doi: 10.1111/jocd.12777] [Medline: $\underline{30238598]}$

15. Williams M, Cunliffe WJ, Williamson B, Forster RA, Cotterill JA, Edwards JC. The effect of local temperature changes on sebum excretion rate and forehead surface lipid composition. Br J Dermatol 1973 Mar;88(3):257-262. [doi: 10.1111/j.1365-2133.1973.tb07544.x] [Medline: 4270005]

16. Adebamowo CA, Spiegelman D, Berkey CS, Danby FW, Rockett HH, Colditz GA, et al. Milk consumption and acne in adolescent girls. Dermatol Online J 2006 May 30;12(4):1. [Medline: 17083856]

17. Adebamowo CA, Spiegelman D, Berkey CS, Danby FW, Rockett HH, Colditz GA, et al. Milk consumption and acne in teenaged boys. J Am Acad Dermatol 2008 May;58(5):787-793 [FREE Full text] [doi: 10.1016/j.jaad.2007.08.049] [Medline: 18194824]

18. Adebamowo CA, Spiegelman D, Danby FW, Frazier AL, Willett WC, Holmes MD. High school dietary dairy intake and teenage acne. J Am Acad Dermatol 2005 Feb;52(2):207-214. [doi: 10.1016/j.jaad.2004.08.007] [Medline: 15692464]

19. Berra B, Rizzo AM. Glycemic index, glycemic load: new evidence for a link with acne. J Am Coll Nutr 2009 Aug;28 Suppl:450S-454S. [doi: 10.1080/07315724.2009.10718111] [Medline: 20234032]

20. Delost GR, Delost ME, Lloyd J. The impact of chocolate consumption on acne vulgaris in college students: A randomized crossover study. J Am Acad Dermatol 2016 Jul;75(1):220-222. [doi: 10.1016/j.jaad.2016.02.1159] [Medline: 27317522]

21. Smith RN, Mann NJ, Braue A, Mäkeläinen H, Varigos GA. A low-glycemic-load diet improves symptoms in acne vulgaris patients: a randomized controlled trial. Am J Clin Nutr 2007 Jul;86(1):107-115. [doi: 10.1093/ajcn/86.1.107] [Medline: 17616769] 
22. Claudel JP, Auffret N, Leccia MT, Poli F, Dréno B. Acne and nutrition: hypotheses, myths and facts. J Eur Acad Dermatol Venereol 2018 Oct;32(10):1631-1637. [doi: 10.1111/jdv.14998] [Medline: 29633388]

23. Borrel V, Thomas P, Catovic C, Racine P, Konto-Ghiorghi Y, Lefeuvre L, et al. Acne and Stress: Impact of Catecholamines on Cutibacterium acnes. Front Med (Lausanne) 2019;6:155 [FREE Full text] [doi: 10.3389/fmed.2019.00155] [Medline: $\underline{31355200]}$

24. Ramsay B, Alaghband-Zadeh J, Carter G, Wheeler MJ, Cream JJ. Raised serum androgens and increased responsiveness to luteinizing hormone in men with acne vulgaris. Acta Derm Venereol 1995 Jul;75(4):293-296 [FREE Full text] [doi: 10.2340/0001555575293296] [Medline: 8578952]

25. Aizawa H, Niimura M. Serum hormone levels in men with severe acne. J Dermatol 1992 Jul;19(7):404-407. [doi: 10.1111/j.1346-8138.1992.tb03249.x] [Medline: 1401498]

26. Wiwanitkit V. Google Trends (GT) related to influenza. Cad Saude Publica 2015 Jun;31(6):1334. [doi: 10.1590/0102-311XCA020615] [Medline: 26200381]

27. Zhang Y, Bambrick H, Mengersen K, Tong S, Hu W. Using Google Trends and ambient temperature to predict seasonal influenza outbreaks. Environ Int 2018 Aug;117:284-291. [doi: 10.1016/j.envint.2018.05.016] [Medline: 29778013]

28. McCartney M. Medicine and the Media. Panic about nuclear apocalypse overshadows Japan's real plight. BMJ 2011 Mar 22;342:d1845. [doi: 10.1136/bmj.d1845] [Medline: 21427033]

29. Lipworth W, Kerridge I, Morrell B, Bonfiglioli C, Forsyth R. Medicine, the media and political interests. J Med Ethics 2012 Dec;38(12):768-770. [doi: 10.1136/medethics-2012-100875] [Medline: 23001949]

30. Ozdalga E, Ozdalga A, Ahuja N. The smartphone in medicine: a review of current and potential use among physicians and students. J Med Internet Res 2012 Sep 27;14(5):e128 [FREE Full text] [doi: 10.2196/jmir.1994] [Medline: 23017375]

31. Jia JL, Polin DJ, Sarin KY. Emerging technologies for health information in dermatology: opportunities and drawbacks of web-based searches, social media, mobile applications, and direct-to-consumer genetic testing in patient care. Semin Cutan Med Surg 2019 Mar 01;38(1):E57-E53. [doi: 10.12788/j.sder.2019.002] [Medline: 31051025]

32. Croley JAA. Emerging roles of social media in dermatology. Cutis 2019 Jan;103(1):E13-E14. [Medline: 30758345]

33. Nyongesa H, Munguti C, Omondi C, Mokua W. Harnessing the power of social media in optimizing health outcomes. Pan Afr Med J 2014;18:290 [FREE Full text] [doi: 10.11604/pamj.2014.18.290.4634] [Medline: 25469184]

34. Heckman CJ, Darlow SD, Ritterband LM, Handorf EA, Manne SL. Efficacy of an Intervention to Alter Skin Cancer Risk Behaviors in Young Adults. Am J Prev Med 2016 Jul;51(1):1-11 [FREE Full text] [doi: 10.1016/j.amepre.2015.11.008] [Medline: 26810358]

35. Robinson JK, Alam M, Ashourian N, Khan M, Kundu R, Laumann AE, et al. Skin cancer prevention education for kidney transplant recipients: a systematic evaluation of Internet sites. Prog Transplant 2010 Dec;20(4):344-349. [doi: 10.7182/prtr.20.4.9877500752888660] [Medline: 21265287]

36. Robinson JK, Gaber R, Hultgren B, Eilers S, Blatt H, Stapleton J, et al. Skin self-examination education for early detection of melanoma: a randomized controlled trial of Internet, workbook, and in-person interventions. J Med Internet Res 2014 Jan 13;16(1):e7 [FREE Full text] [doi: 10.2196/jmir.2883] [Medline: 24418949]

37. Wang H, Wang Y, Liang C, Li Y. Assessment of Deep Learning Using Nonimaging Information and Sequential Medical Records to Develop a Prediction Model for Nonmelanoma Skin Cancer. JAMA Dermatol 2019 Sep 04:1 [FREE Full text] [doi: 10.1001/jamadermatol.2019.2335] [Medline: 31483437]

38. Han SS, Lim W, Kim MS, Park I, Park GH, Chang SE. Interpretation of the Outputs of a Deep Learning Model Trained with a Skin Cancer Dataset. J Invest Dermatol 2018 Oct;138(10):2275-2277 [FREE Full text] [doi: 10.1016/j.jid.2018.05.014] [Medline: 29864434]

39. Zipprich J, Winter K, Hacker J, Xia D, Watt J, Harriman K, Centers for Disease Control and Prevention (CDC). Measles outbreak--California, December 2014-February 2015. MMWR Morb Mortal Wkly Rep 2015 Feb 20;64(6):153-154 [FREE Full text] [Medline: 25695321]

Edited by $G$ Eysenbach; submitted 16.04.20; peer-reviewed by H Santos, $R$ Kaczmarczyk; comments to author 06.07.20; revised version received 17.07.20; accepted 20.07.20; published 26.10.20

Please cite as:

Park TH, Kim WI, Park S, Ahn J, Cho MK, Kim S

Public Interest in Acne on the Internet: Comparison of Search Information From Google Trends and Naver

J Med Internet Res 2020;22(10):e19427

URL: http://www.jmir.org/2020/10/e19427/

doi: $10.2196 / 19427$

PMID: $\underline{3104003}$ 
(C)Tae Heum Park, Woo Il Kim, Suyeon Park, Jaeouk Ahn, Moon Kyun Cho, Sooyoung Kim. Originally published in the Journal of Medical Internet Research (http://www.jmir.org), 26.10.2020. This is an open-access article distributed under the terms of the Creative Commons Attribution License (https://creativecommons.org/licenses/by/4.0/), which permits unrestricted use, distribution, and reproduction in any medium, provided the original work, first published in the Journal of Medical Internet Research, is properly cited. The complete bibliographic information, a link to the original publication on http://www.jmir.org/, as well as this copyright and license information must be included. 